\title{
Stability Indicating HPLC Method for Simultaneous Quantification of Trihexyphenidyl Hydrochloride, Trifluoperazine Hydrochloride and Chlorpromazine Hydrochloride from Tablet Formulation
}

\author{
P. SHETTI* and A. VENKATACHALAM \\ Department of Chemistry, Bhavan's College, \\ Andheri (West), Mumbai - 400058, Maharashtra, India. \\ pgshetti@yahoo.co.in
}

Received 2 November 2009; Accepted 1 January 2010

\begin{abstract}
A new, simple, precise, rapid, selective and stability indicating reversed-phase high performance liquid chromatographic (HPLC) method has been developed and validated for simultaneous quantification of trihexyphenidyl hydrochloride, trifluoperazine hydrochloride and chlorpromazine hydrochloride from combined tablet formulation. The method is based on reverse-phase using C-18 (250x4.6) $\mathrm{mm}, 5 \mu \mathrm{m}$ particle size column. The separation is achieved using isocratic elution by methanol and ammonium acetate buffer $(1 \% \mathrm{w} / \mathrm{v}, \mathrm{pH} 6.5)$ in the ratio of $85: 15 \mathrm{v} / \mathrm{v}$, pumped at flow rate $1.0 \mathrm{~mL} / \mathrm{min}$ and $\mathrm{UV}$ detection at $215 \mathrm{~nm}$. The column is maintained at $30{ }^{\circ} \mathrm{C}$ through out the analysis. This method gives baseline resolution. The total run time is $15 \mathrm{~min}$. Stability indicating capability is established buy forced degradation experiment. The method is validated for specificity, accuracy, precision and linearity as per International conference of harmonisation (ICH). The method is accurate and linear for quantification of trihexyphenidyl hydrochloride, trifluoperazine hydrochloride and Chlorpromazine hydrochloride between $5-15 \mu \mathrm{g} / \mathrm{mL}, 12.5-37.5 \mu \mathrm{g} / \mathrm{mL}$ and $62.5-187.5 \mu \mathrm{g} / \mathrm{mL}$ respectively.
\end{abstract}

Keywords: Trihexyphenidyl hydrochloride, Trifluoperazine hydrochloride, Chlorpromazine hydrochloride, HPLC, Stability indicating Assay method, Simultaneous Assay method.

\section{Introduction}

Trihexyphenidyl is chemically 1-cyclohexyl-1-phenyl-3-(1-piperidyl)propan-1-ol, it is available in hydrochloride salt form i.e. Trihexyphenidyl hydrochloride (THP) and its chemical structure is as shown in Figure 1(A). It is an antipsychotic drug and used for the symptomatic treatment of Parkinson's disease in mono- and combination therapy. The drug is also commonly used to treat extrapyramidal side effects occurring during antipsychotic treatment. 
It is white or almost white, crystalline powder, slightly soluble in water, sparingly soluble in alcohol and in methylene chloride. It is melting at about $250{ }^{\circ} \mathrm{C}$, with decomposition. The acid dissociation constant ${ }^{1}$ of THP is $\mathrm{pKa}=8.7$ and partition coefficient of THP in octanol/water system ${ }^{1}$ is $\log \mathrm{P}=4.5$.

Trifluoperazine is chemically 10-[3-(4-methylpiperazin-1-yl)propyl]-2-(trifluoromethyl)$10 H$-phenothiazine, it is available in hydrochloride salt i.e. Trifluoperazine hydrochloride (TFP) and its chemical structure is as shown in Figure 1(B). It is indicated for use in agitation and patients with behavioral problems, severe nausea and vomiting as well as severe anxiety.

It is white to pale yellow, crystalline powder, hygroscopic, freely soluble in water, soluble in alcohol. It melts at about $242{ }^{\circ} \mathrm{C}$, with decomposition. The acid dissociation constant ${ }^{2}$ of TFP is $\mathrm{pKa}_{1}=3.8$ and $\mathrm{pKa}_{2}=8.4$. Partition coefficient of THP in octanol $/$ water system $^{3}$ is $\log \mathrm{P}=5.4$.

Chlorpromazine is chemically 3-(2-chloro- $10 H$-phenothiazin-10-yl)- $N, N$-dimethylpropan-1-amine, it is available in hydrochloride salt i.e. chlorpromazine hydrochloride (CLP) and its chemical structure is as shown in Figure 1(C). Chlorpromazine and many other phenothiazine derivatives, are very lipophilic molecules that readily bind with membranes and proteins. Approximately $95-98 \%$ of the drug is bound in the plasma; $85 \%$ of the drug is bound to the plasma protein albumin. Highest concentrations of the drug can be found in the brain, lung, and other tissues that receive a high supply of blood.

It is white or almost white crystalline powder. It is very soluble in water, freely soluble in ethanol (96 per cent). It decomposes on exposure to air and light. Its melting point is at about $196{ }^{\circ} \mathrm{C}$. The acid dissociation constant ${ }^{4}$ of CLP is $\mathrm{pKa}=9.30$. The partition coefficient of CLP in octanol/water system ${ }^{4}$ is $\log \mathrm{P}=5.35$.

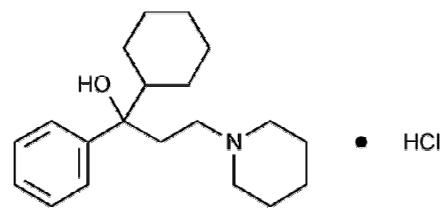

(A)<smiles>CN1CCN(CCCN2c3ccccc3Sc3ccc(C(F)(F)F)cc32)CC1</smiles>

(B)<smiles>CN(C)CCCN1c2ccccc2Sc2ccc(Cl)cc21</smiles>

(C)

Figure 1. Chemical structure of (A)THP, (B)TFP and (C)CLP. 
The literature survey revels that there are verity of analytical method for the quantification of THP, TFP and CLP from mono formulation or from biological matrix. The available methods for quantification of THP from formulation or from biological samples are based on $\mathrm{LC}^{-\mathrm{MS}^{5}}, \mathrm{GC}^{6}$, Capillary zone electrophoresis ${ }^{7-8}$, HPLC with UV detector ${ }^{9}$, UV-spectroscopy ${ }^{10}$ and TLC and for quantification ${ }^{11}$ of TFP from formulation or from biological samples are based on LC-MS ${ }^{12}$, HPLC with UV detector ${ }^{13-16}$, UV-spectroscopy ${ }^{15,17-19}$, TLC $^{15,20}$, GC-MS $^{21}$, voltametric ${ }^{22}$ and Fluorimetric ${ }^{23}$, however for quantification of CLP from formulation or from biological samples are based on LC-MS ${ }^{24-25}$, HPLC with UV detector $^{26-32}$, UV-spectroscopy ${ }^{33-35}$, GC-MS ${ }^{36,37}$, TLC ${ }^{38}$, Potentiometer ${ }^{39-41}$, NMR ${ }^{42}$, Radioimmunoassay $^{43}$, Fluorimetry ${ }^{44}$, Chemiluminescence ${ }^{45}$, Electron spin resonance spectroscopy $^{46}$.

Apart from above published method, an individual drug substance monograph for THP, TFP and CLP are available in USP (United State Pharmacopeia) ${ }^{47}$ and BP (British Pharmacopoeia) ${ }^{48}$.

Among the above reported methods some describes quantification of individual content by sophisticated instrument like LC-MS, GC-MS, NMR etc. Since Mass spectroscope itself is a unique detector whose principle detection property depends on the mass of the analyte and not the elution time from column, thus complete chromatographic separation of all the analyte is not mandatory also the cost of these analysis for routine check is very high. There are some methods based on UV-spectroscopy or potentiometeric assay which is not a stability indicating and some are based on TLC which is time consuming.

A comprehensive literature search revealed the lack of a suitable procedure for the simultaneous determination of these three drugs in pharmaceutical dosage forms. The basic purpose of our work was to develop the cost effective stability indicating HPLC method for the simultaneous determination of THP, TFP and CLP. There after this method was validated as per $\mathrm{ICH}^{50}$ guideline and successfully applied for the analysis of commercially available samples. In this study we avoided the use of acetonitrile due to its scarcity in market, instead methanol was used which is readily available and environmental friendly.

\section{Experimental}

All the experiments were performed with pharmaceutical-grade THP, TFP and CLP. The working standards of trihexyphenidyl hydrochloride, trifluoperazine hydrochloride and Chlorpromazine hydrochloride were kindly gifted by Reliance Formulation Pvt. LTD., Ahmedabad, India. Methanol was obtained from J. T. baker (NJ, USA); ammonium acetate, sodium metabisulphite and sodium hydroxide was supplied by Merck, (Mumbai, India). AnalR grade hydrochloric acid and hydrogen peroxide was supplied by Qualigen's fine chemicals (Mumbai, India).

'High purity water was obtained from Millipore, Milli-Q (Milford, MA, USA) purification system. The pharmaceutical preparation, declaring Trihexyphenidyl hydrochloride $2 \mathrm{mg}$, trifluoperazine hydrochloride $5 \mathrm{mg}$ and chlorpromazine hydrochloride $25 \mathrm{mg}$. and excipients were obtained from local drug store. Buffer was prepared by dissolving $10 \mathrm{~g}$ of ammonium acetate in one litre water.

\section{Chromatographic system}

Analysis were performed on Alliance HPLC system (Waters, Milford, USA), consisting of 2695 separation module and 2998 photo diode array detector. System control, data collection 
and data processing were accomplished using WATERS EMPOWER ${ }^{\mathrm{TM}}$ chromatography software. Analytical column used was INERTSIL ODS-SP $(250 \times 4.6 \mathrm{~mm}, 5 \mu)$. The separation of THP, TFP and CLP were achieved by using mobile phase consisting of methanol and ammonium acetate buffer $(1.0 \% \mathrm{w} / \mathrm{v}, \mathrm{pH} 6.5)$ in the proportion of $85: 15 \mathrm{v} / \mathrm{v}$. The injection volume is $20 \mu \mathrm{L}$, column temperature $30^{\circ} \mathrm{C}$ and $\mathrm{UV}$ detection at $215 \mathrm{~nm}$. The mixture of methanol and 1\% ammonium acetate buffer in $85: 15 \mathrm{v} / \mathrm{v}$ proportion is used as diluent. This diluent was used for the standard and sample preparation. The approximate retention time for THP, CLP and TFP is about $5.7 \mathrm{~min}, 7.5 \mathrm{~min}$ and $9.4 \mathrm{~min}$ respectively.

\section{Assay standard solution preparation}

Standard solution was prepared by dissolving standard substance in diluent to obtain solution containing $10 \mu \mathrm{g} / \mathrm{mL}$ of THP, $25 \mu \mathrm{g} / \mathrm{mL}$ of TFP and $125 \mu \mathrm{g} / \mathrm{mL}$ of CLP.

\section{Sample preparation}

Weighed and transfered the 5 tablets to $100 \mathrm{~mL}$ amber colour volumetric flask and $20 \mathrm{~mL}$ of diluent was added and sonicated for 15 min and diluted up to mark with diluent. Further 5 $\mathrm{mL}$ of this solution was diluted to $50 \mathrm{~mL}$ with diluent. The above solutions were then filtered through 0.45 micron nylon filter. The filtrate collected after discarding first few millilitres was injected on to the above chromatographic system. All the solutions were protected from light.

\section{Method validation}

\section{System suitability}

System suitability parameters were measured so as to verify the system performance. System precision was determined on five replicate injections of standard preparations. All important characteristics including capacity factor, USP tailing factor and USP plate count were measured

\section{Specificity}

It is the ability of analytical method to measure the analyte response in the presence of its potential degradants and placebo peaks. The specificity of the HPLC method was determined by injecting diluent, placebo preparation, standard preparation and sample preparation.

Forced degradation studies were performed to demonstrate selectivity and stability indicating capability of the proposed method. The tablet samples were exposed to photolytic degradation (i.e. in UV and white light for 1.2 million lux hours), thermal degradation $\left(105{ }^{\circ} \mathrm{C}, 4 \mathrm{~h}\right)$. The samples solution was exposed to acidic $\left(0.1 \mathrm{~N} \mathrm{HCl}, 80{ }^{\circ} \mathrm{C} 30 \mathrm{~min}\right)$, alkaline $\left(0.1 \mathrm{~N} \mathrm{NaOH}, 80{ }^{\circ} \mathrm{C}, 60 \mathrm{~min}\right)$, oxidising $\left(0.1 \% \mathrm{H}_{2} \mathrm{O}_{2}, 30{ }^{\circ} \mathrm{C}, 30 \mathrm{~min}\right)$, Reducing ( $0.1 \%$ sodium metabisulphite, $\left.30{ }^{\circ} \mathrm{C}, 30 \mathrm{~min}\right)$. Also the standards of THP, TFP and CLP were exposed to the same above stress condition, individually and in combination of each other to identify source of degradation peak. All exposed tablet samples and standards were then analysed by the proposed method.

\section{Limit of detection (LOD) and Limit of Quantitation ( $L O Q)$}

As per ICH LOD and LOQ is not required to be evaluated for the method of quantification of drug from formulation, in this study LOD and LOQ was determined additionally to express lower level of detection capability of the method. The LOD and LOQ of THP, TFP and CLP were determined statistically using residual error/steyx method as defined in ICH 
guidelines. The linearly increasing concentration of THP, TFP and CLP mixture were injected and the obtained areas were plotted against respective concentration to get predication linearity plot. The LOD concentration (in $\mu \mathrm{g} / \mathrm{mL}$ ) is 3.3 times ratio of steyx and slope of the prediction calibration plot while LOQ concentration (in $\mu \mathrm{g} / \mathrm{mL}$ ) is 10 times the ratio of steyx and slope of the prediction calibration plot, which meets the criteria defined by ICH guidelines.

\section{Linearity}

Linearity was demonstrated from $50 \%$ to $150 \%$ of standards concentration using seven calibration levels of $50 \%, 70 \%, 80 \%, 100 \%, 120 \%, 140 \%$ and $150 \%$ (i.e. for THP 5, 7, 8, $10,12,14,15 \mu \mathrm{g} / \mathrm{mL}$; for TFP $12.5,17.5,20,25,3,35,37.5 \mu \mathrm{g} / \mathrm{mL}$ and for CLP it is 62.5 , $87.5,100,125,150,187.50 \mu \mathrm{g} / \mathrm{mL})$. The method of linear regression was used for data evaluation.

\section{Precision}

Precision was investigated using sample preparation procedure for six real samples of commercial brand (RELICALM SF TABLETS, Reliance Formulation Pvt. LTD., Ahmedabad, India) and analysing by proposed method. Intermediate precision was studied by performing the analysis on different day.

\section{Accuracy}

To confirm the accuracy of the proposed method, recovery experiments were carried out by standard addition technique. Three different levels (50\%, 100\% and 150\% w.r.t. working concentration) of standards were added to pre-analysed placebo preparation in triplicate. The percentage recoveries of THP, TFP and CLP at each level were determined. The mean of percentage recoveries $(n=9)$ and the relative standard deviation was calculated.

\section{Robustness}

The robustness as measure of method capacity to remain unaffected by small, but deliberate changes in chromatographic conditions was studied by testing influence of small changes in column temperature $\left(30{ }^{\circ} \mathrm{C} \pm 5{ }^{\circ} \mathrm{C}\right)$, change in mobile phase flow rate $(1 \pm 0.1 \mathrm{~mL} / \mathrm{min})$ and change in mobile phase composition on the system suitability parameter and on assay determination.

\section{Stability in analytical sample solution}

Stability of sample and standard solution was established by storage of sample solution at ambient temperature $\left(25^{\circ} \mathrm{C}\right)$ for $24 \mathrm{~h}$ and assay was determine and compared against freshly prepared standard.

\section{Results and Discussion}

\section{HPLC method development and optimisation}

The main criteria for development of successful HPLC method for determination of THP, TFP and CLP in tablets where; the method should be fast, specific, accurate, reproducible, robust, stability indicating and straightforward enough for routine used in quality control.

\section{Selection of detection wavelength}

The UV spectra between 190 and $400 \mathrm{~nm}$ for individual drugs THP, TFP and CLP at working concentration in diluent, are shown in Figure 2. 


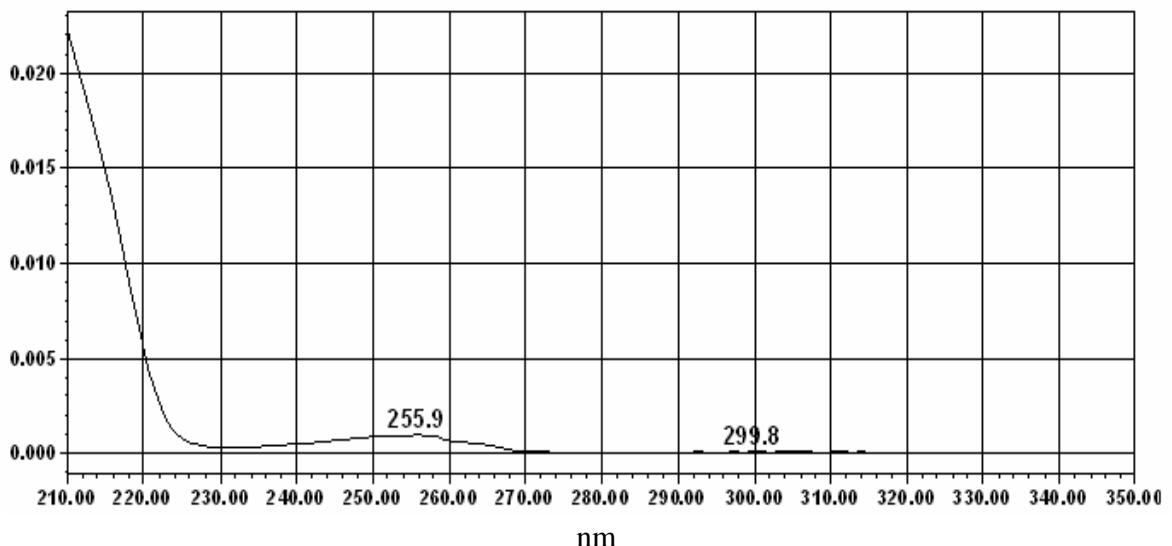

(a) THP $(10 \mu \mathrm{g} / \mathrm{mL}))$ in 20:80 (v/v) mixture of water and methanol.

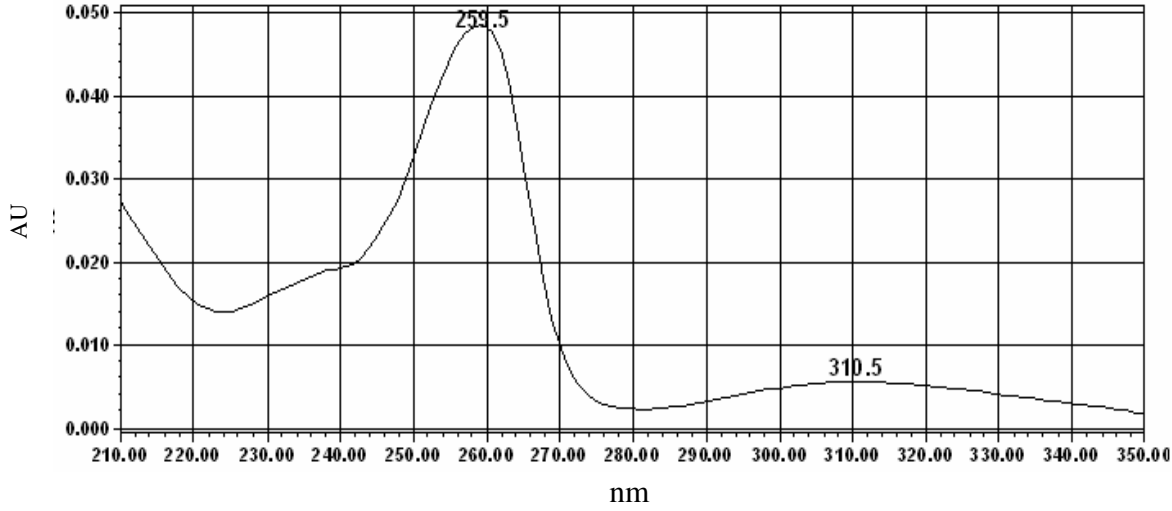

(b) TFP $(25 \mu \mathrm{g} / \mathrm{mL})$ in 20:80 (v/v) mixture of water and methanol.

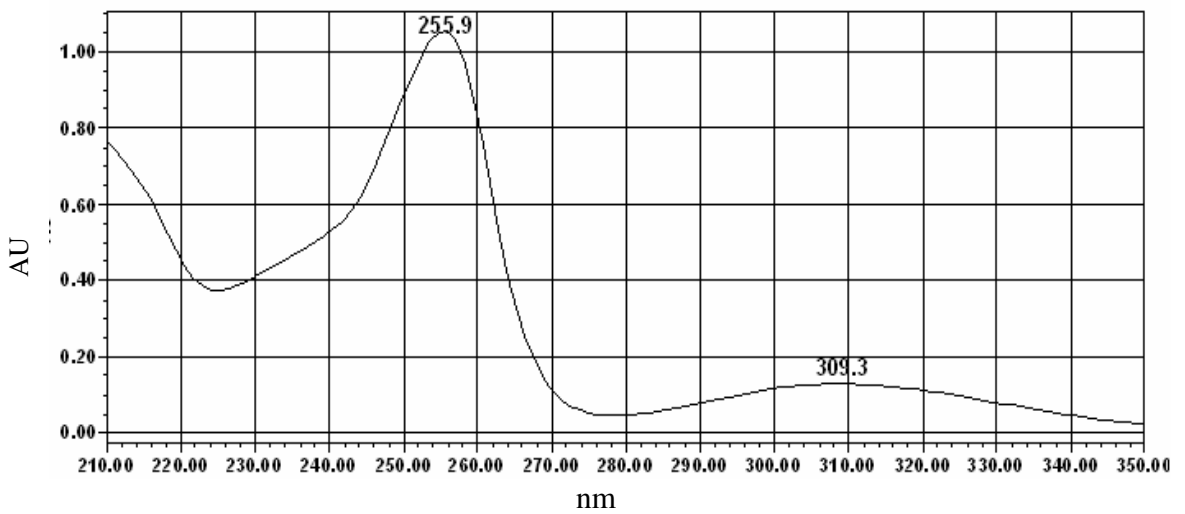

(c) CLP $(125 \mu \mathrm{g} / \mathrm{mL})$ in 20:80 (v/v) mixture of water and methanol.

Figure 2. UV Spectra of: (a) THP $(10 \mu \mathrm{g} / \mathrm{mL})$; (b) TFP $(25 \mu \mathrm{g} / \mathrm{mL})$; (c) CLP $(125 \mu \mathrm{g} / \mathrm{mL})$ in 20:80 (v/v) mixture of water and methanol.

As observed from UV-spectra in Figure 2, TFP and CLP have good absorption characteristic as compared to THP, where TFP exhibits two crusts at $260 \mathrm{~nm}$ and $311 \mathrm{~nm}$, CLP 
also have two crusts at $256 \mathrm{~nm}$ and at $309 \mathrm{~nm}$ where as THP exhibits two crust one at $256 \mathrm{~nm}$ and other at $300 \mathrm{~nm}$ but having very low absorbance value. It has been observed that THP has good absorption characteristics at short wavelength where TFP and CLP also have good absorption characteristics.

In the formulation mixture the content of THP is less compared to other two drug component. Hence short wavelength of detection i.e. $215 \mathrm{~nm}$ had selected in order to quantify all three components properly.

\section{Selection of column}

The USP and BP monograph for THP formulation states RP-HPLC method using C-18 column for its assay test and for CLP formulation states UV-spectroscopic method. While for TFP formulation USP states RP-HPLC and BP states UV-spectroscopic method for assay test. On the basis of various trails Inertsil ODS-SP (250x4.6) $\mathrm{mm}, 5 \mu \mathrm{m}$ was optimised in order to elute THP, TFP and CLP in short time.

\section{Selection of mobile phase}

Here the pKa value of components is utilised for the selection of mobile phase. The pKa value of THP, TFP and CLP are 8.7, 8.4 and 9.3 respectively. Hence the Ammonium acetate which is having $\mathrm{pKa}$ value of 8.5 , was selected as the buffer at concentration of $1 \% \mathrm{w} / \mathrm{v}$. As pre-decided the methanol was used as an organic component in mobile phase. The separation between all the three components was studied using different proportion of Buffer and methanol in mobile phase. It has been observed that as the proportion of buffer increases in mobile phase the retention time of all the component increases. Thus the optimised mobile phase proportion was buffer: methanol $(15: 85) \mathrm{v} / \mathrm{v}$, where buffer is ammonium acetate (1\% w/v, $\mathrm{pH} 6.5)$. The methanol is having UV cut off at $205 \mathrm{~nm}$ and our optimised detection wavelength was $215 \mathrm{~nm}$. Hence we have done the assay of all three drug component individually (at working concentration) by proposed method here and compared with there respective assay by method published in respective monograph of USP. Both the assay values were similar and RSD for assay by two methods for all three components were within $2 \%$, hence use of methanol in mobile phase and detection wavelength of 215 does not have impact on quantification of all three drug components from tablets formulation. The $\mathrm{pH}$ stability and visual clarity if the mobile phase was studied over $48 \mathrm{~h}$ and found to be stable.

In order to study the effect of the mobile phase $\mathrm{pH}$ on retention time of all the three components, the retention time of all three components were plotted against $\mathrm{pH}$ of mobile phase in Figure 3. While assessing $\mathrm{pH} /$ retention time profile for all three components, composition of mobile phase was kept constant i.e. buffer: methanol (15:85) v/v. Figure 3 indicates that the critical separation of all three components can be achieved at $\mathrm{pH} 7.0$ which is about 1.5 unit less then $\mathrm{pKa}$ value of all three components. Hence mobile phase composition of ammonium acetate buffer ( $1 \% \mathrm{w} / \mathrm{v}, \mathrm{pH} 6.5)$ and methanol, in the ratio of 15 : $85(\mathrm{v} / \mathrm{v})$ at $\mathrm{pH} 7.0$ was found most appropriate for robust resolution of all three components with approximate retention time of about $5.7 \mathrm{~min}, 7.5 \mathrm{~min}$ and $9.4 \mathrm{~min}$ for THP, CLP and TFP respectively.

\section{Sample preparation}

The intact tablets were used for sample preparation to prevent the loss of drug content during crushing. Since TFP and CLP are light sensitive all the preparations were prepared in diffused light and in amber coloured volumetric flask. 


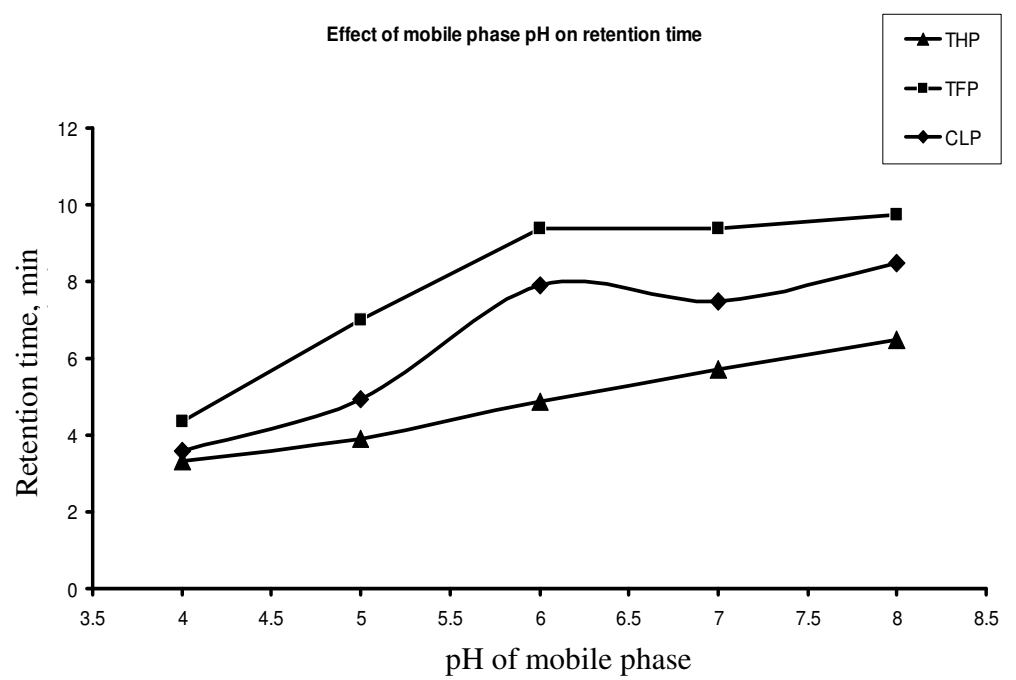

Figure 3. Effect of mobile phase $\mathrm{pH}$ on retention time of THP, TFP and CLP keeping mobile phase proportion constant as Ammonium acetate buffer $(1 \% \mathrm{w} / \mathrm{v})$ : methanol $(15: 85) \mathrm{v} / \mathrm{v}$.

\section{Validation}

After satisfactory development of method it was subjected to method validation with respect to parameters like Specificity, Linearity, Precision, Accuracy, Robustness as per the $\mathrm{ICH}^{50}$ guidelines

\section{System suitability}

The percentage of R.S.D. for area count of five replicate injections was below $2.0 \%$. The results of system precision are presented in Table 1. Low values of R.S.D. of replicate injection indicate that system is precise.

Table 1. System precision.

\begin{tabular}{|c|c|c|c|c|c|c|c|c|c|c|}
\hline \multirow[t]{2}{*}{ Analyte } & \multicolumn{2}{|c|}{$\begin{array}{c}\text { System precision } \\
\text { (Area) }\end{array}$} & \multicolumn{2}{|c|}{$\begin{array}{l}\text { Retention } \\
\text { time, min }\end{array}$} & \multicolumn{2}{|c|}{$\begin{array}{l}\text { Tailing } \\
\text { factor. }\end{array}$} & \multicolumn{2}{|c|}{$\begin{array}{l}\text { Capacity } \\
\text { factor (k') }\end{array}$} & \multicolumn{2}{|c|}{$\begin{array}{c}\text { Column } \\
\text { efficiency }(\mathrm{N})\end{array}$} \\
\hline & Mean $^{\mathrm{a}}$ & $\% \mathrm{RSD}^{\mathrm{a}}$ & Mean $^{a}$ & $\% \mathrm{RSD}^{\mathrm{a}}$ & Mean & $\% \mathrm{RSD}^{\mathrm{a}}$ & Mean $^{a}$ & $\% \mathrm{RSD}^{2}$ & ${ }^{M e a n}{ }^{a}$ & $\% \mathrm{RSD}^{\mathrm{a}}$ \\
\hline TPH & 195286 & 0.17 & 5.71 & 0.10 & 1.27 & 0.70 & 2.81 & 0.13 & 4175 & 0.28 \\
\hline TFP & 272814 & 0.24 & 9.46 & 0.05 & 1.30 & 1.26 & 4.03 & 0.12 & 7588 & 0.62 \\
\hline CLP & 8805107 & 0.24 & 7.54 & 0.09 & 1.04 & 0.00 & 5.31 & 0.00 & 6885 & 0.20 \\
\hline
\end{tabular}

${ }^{a}$ Determined on average of five replicate injection of standard preparation.

\section{Specificity}

The specificity of method was determined by injecting diluent, placebo preparation, standard preparation and sample preparation. No peak was interfering with principle peak. All the principle peaks were resolved base to base. The Peak purity of principal peaks were checked on PDA detector and found to be spectrally pure. The spectral purity of THP, TFP and CLP is shown in Figure 4 (A), \& (B) and IV (C). The typical chromatogram of sample preparation is as shown in Figure 5.

The results of forced degradation study are given in Table 2. THP was found to be sensitive to oxidative degradation, where assay was drop to $89.4 \%$. TFP was found to be sensitive to thermal degradation, where assay was drop to $91.9 \%$. CLP was found to be sensitive 
to acid hydrolysis where assay was drop to $89.1 \%$. Peak due to THP, TFP and CLP were investigated for spectral purity on PDA detector for all stressed condition samples and found to be spectrally pure. The forced degradation study on individual standards does not produce any peak eluting at retention time of three principle peak. The max plot of chromatograms for forced degradation of samples and standard were also checked to ensure that no peak is missed due to use of wavelength $215 \mathrm{~nm}$. Thus indicating that method is more specific and selective for all the three drugs.

Table 2. Forced degradation study data.

\begin{tabular}{lccc}
\hline Degradation condition & \multicolumn{3}{c}{$\%$ Assay } \\
\cline { 2 - 4 } & THP & TFP & CLP \\
\hline No degradation (Control) & 100.5 & 101.1 & 100.2 \\
Acidic hydrolysis $\left(0.1 \mathrm{M} \mathrm{HCl}\right.$ solution, $\left.80{ }^{\circ} \mathrm{C}, 30 \mathrm{~min}\right)$ & 90.1 & 96.7 & 98.6 \\
Alkali hydrolysis $\left(0.1 \mathrm{M} \mathrm{NaOH}\right.$ solution, $\left.30{ }^{\circ} \mathrm{C}, 30 \mathrm{~min}\right)$ & 90.6 & 95.1 & 89.1 \\
Oxidative $\left(0.1 \% \mathrm{H} 2 \mathrm{O} 2\right.$ solution, $\left.30{ }^{\circ} \mathrm{C}, 30 \mathrm{~min}\right)$ & 89.4 & 94.8 & 92.0 \\
Reductive $\left(0.1 \% \mathrm{Na}-\mathrm{metabisulphite,} 30^{\circ} \mathrm{C}, 30 \mathrm{~min}\right)$ & 90.1 & 92.5 & 90.5 \\
Thermal degradation $105{ }^{\circ} \mathrm{C}, 24 \mathrm{~h}$ & 90.9 & 91.9 & 94.6 \\
UV light-1.2million lux hours & 90.5 & 92.8 & 95.5 \\
White light-1.2million lux hours & 91.3 & 95.0 & 96.4 \\
\hline
\end{tabular}

The spectral purity on PDA detector for THP in oxidative degradation, for TFP in thermal degradation and for CLP in acid hydrolysis is shown in Figure 4 (D), 4 (E) and 4 (F) respectively.
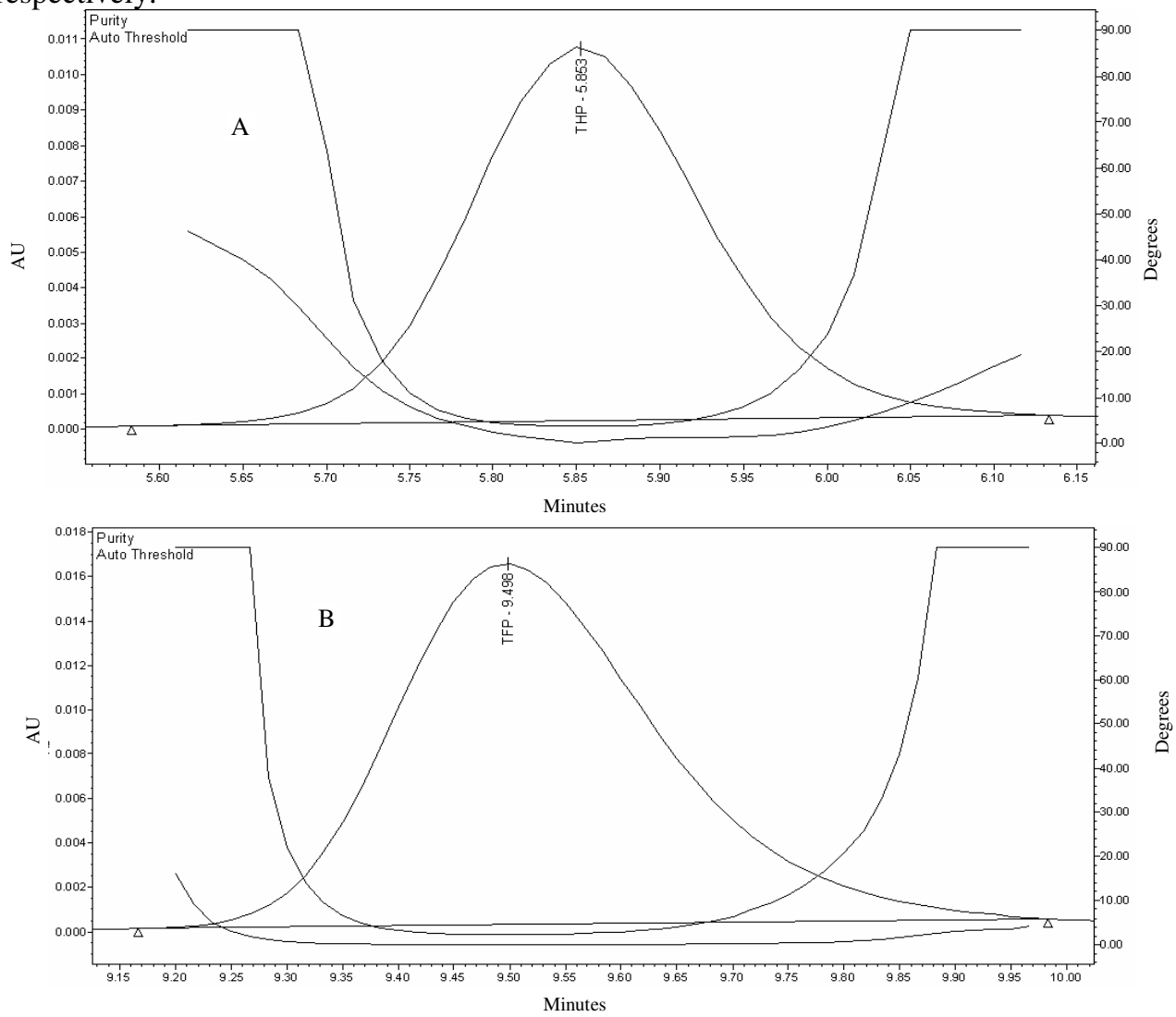

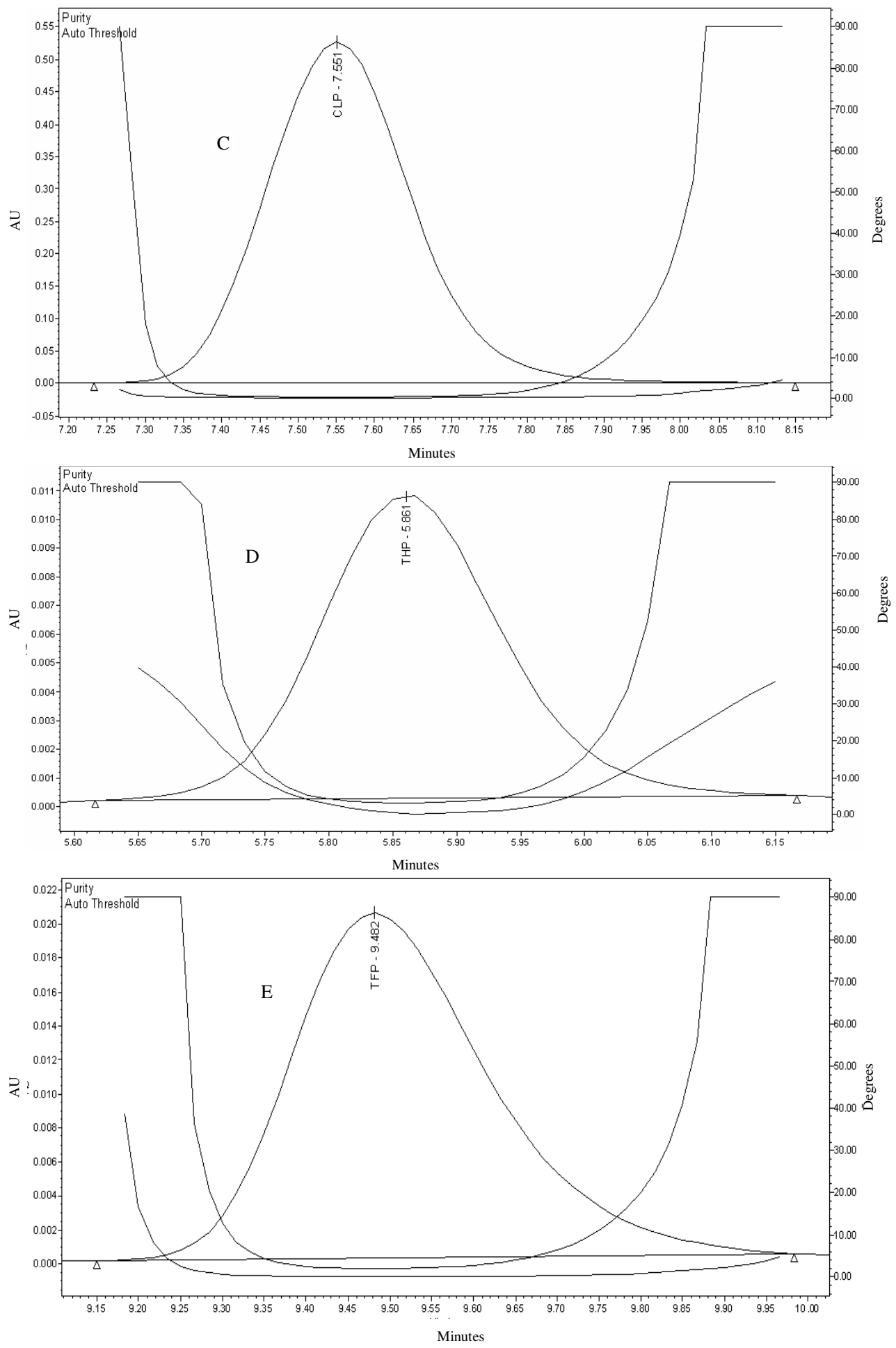


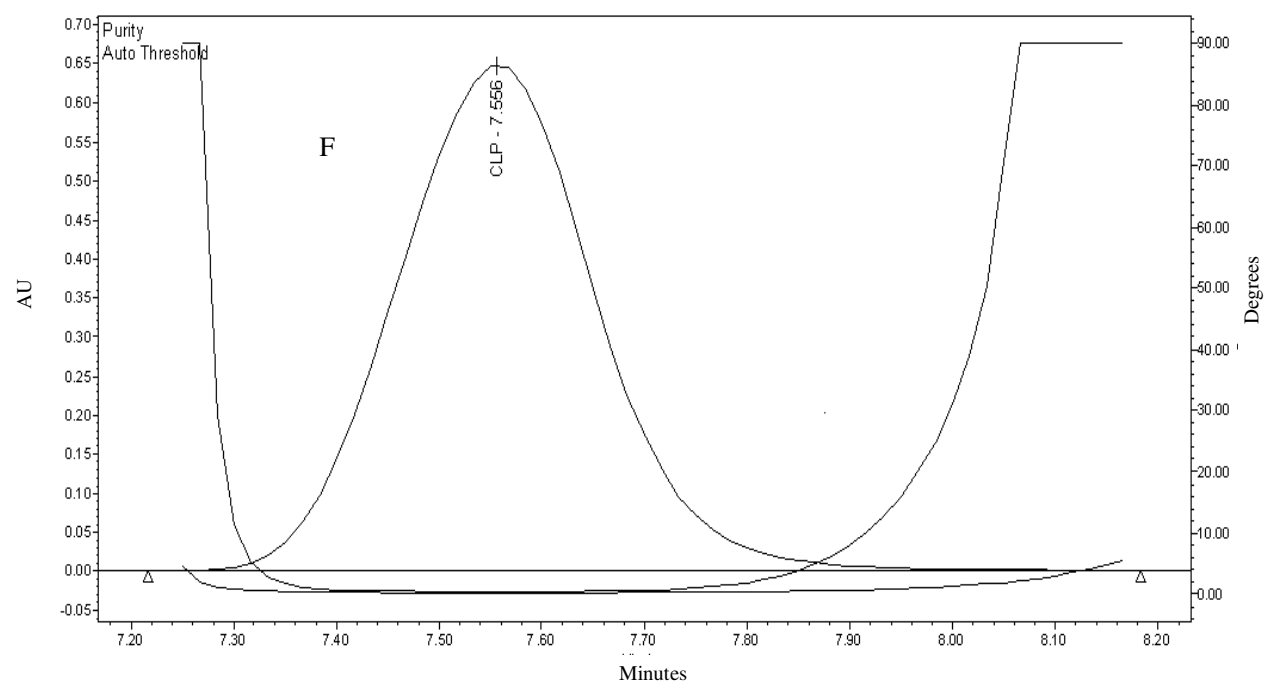

Figure 4. PDA peak purity for THP, TFP \& CLP in standard preparation are express in fig (A), (B) \& (C) respectively; the peak purity for THP in oxidative degradation, TFP in thermal degradation and CLP in acid hydrolysis are express in Figure (D), (E) \& (F) respectively, were measured on WATERS ${ }^{\mathrm{TM}} 2998$ PDA detector.

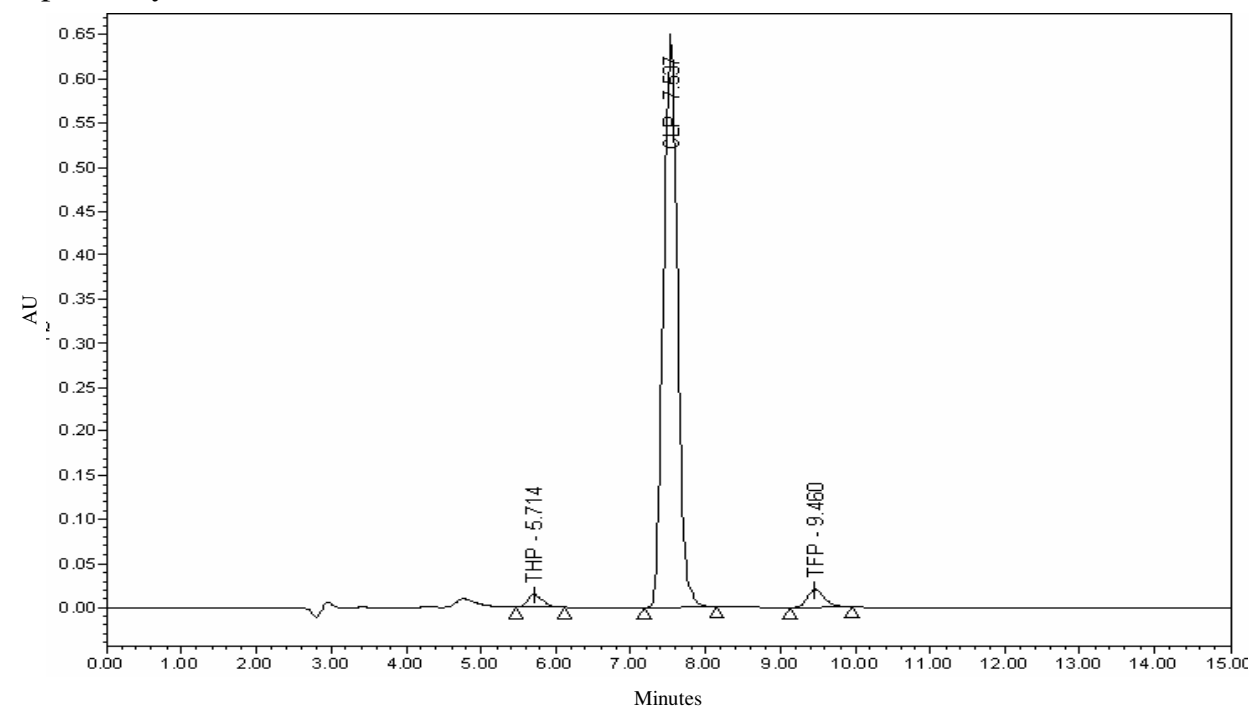

Figure 5. Typical chromatogram for sample preparation containing $10 \mu \mathrm{g} / \mathrm{mL}$ of THP, $25 \mu \mathrm{g} / \mathrm{mL}$ of TFP and $125 \mu \mathrm{g} / \mathrm{mL}$ of CLP chromatographed on INERTSIL-ODS-SP column (250x4.6) $\mathrm{mm}, 5 \mu \mathrm{m}$ in isocratic elution using ammonium acetate $(1 \%, \mathrm{w} / \mathrm{v})$ and Methanol in proportion of $85: 15 \mathrm{v} / \mathrm{v}$ used as mobile phase and measured at $215 \mathrm{~nm}$.

\section{Limit of detection (LOD) and limit of quantitation (LOQ)}

The LOD and LOQ were determined based on statistical calculation using predication calibration curve. The LOD and LOQ results for THP, TFP and CLP were presented in Table 3. 
Table 3. Predication linearity plot results and LOD, LOQ results.

\begin{tabular}{lccc}
\hline Parameter & THP & TFP & CLP \\
\hline Linearity range, $\mu \mathrm{g} / \mathrm{mL}$ & $0.055-0.103$ & $0.080-0.150$ & $0.015-0.028$ \\
Correlation coefficient & 0.9954 & 0.9929 & 0.9960 \\
Linearity equation & $\mathrm{y}=22334 \mathrm{x}-222$ & $\mathrm{y}=16431 \mathrm{x}-292$ & $\mathrm{y}=83732 \mathrm{x}-282$ \\
Steyx & 48.9930 & 64.4992 & 46.4682 \\
Slope & 22333.803 & 16431.473 & 83731.691 \\
$\mathrm{LOD}$, in $\mu \mathrm{g} / \mathrm{mL}$ & 0.0072 & 0.0130 & 0.0018 \\
$\mathrm{LOQ}$, in $\mu \mathrm{g} / \mathrm{mL}$ & 0.0219 & 0.0393 & 0.0055 \\
\hline
\end{tabular}

\section{Linearity}

The calibration curve was constructed for THP, TFP and CLP. The response was found to be linear from $50 \%$ level to $150 \%$ of working concentration. For all compound the correlation coefficient was greater than 0.999 . Correlation coefficient and linearity equation for all three components are presented in Table 4

Table 4. Linearity plot results

\begin{tabular}{cccc}
\hline Analyte & Linearity range $^{\mathrm{a}}$ & $\begin{array}{c}\text { Correlation }^{\mathrm{c}} \\
\text { coefficient }^{\mathrm{a}}\end{array}$ & Linearity equation $^{\mathrm{a}}$ \\
\hline THP & $5-15$ & 0.999 & $\mathrm{y}=19407 \mathrm{x}+3957$ \\
TFP & $12.5-37.5$ & 0.999 & $\mathrm{y}=14468 \mathrm{x}-17197$ \\
CLP & $62.5-187.5$ & 0.999 & $\mathrm{y}=73804 \mathrm{x}-283317$ \\
\hline
\end{tabular}

${ }^{\text {a }}$ Based on Linearity plot for the seven concentration ranging from $50 \%$ to $150 \%$ of standard concentration.

\section{Precision}

The average \% assay for ( $\mathrm{n}=6$ ) of THP was 100.4 and TFP was 100.0 and CLP was 101.6, with $\%$ RSD of 0.71 and 0.34 and 0.41 respectively. The results for the system suitability parameter given in Table 1 . The result for Method precision and Intermediate precision is given in Table 5. The low \% RSD indicates the method is precise.

Table 5. Repeatability, intermediate precision, accuracy and stability in analytical solution result

\begin{tabular}{|c|c|c|c|}
\hline Parameter & THP & TFP & CLP \\
\hline Repeatability (Mean \% Assay) $^{a}$ & 100.4 & 100.0 & 101.6 \\
\hline Repeatability (\% RSD) ${ }^{\mathrm{a}}$ & 0.71 & 0.34 & 0.41 \\
\hline Intermediate precision (Mean $\%$ Assay) ${ }^{a}$ & 100.2 & 101.2 & 100.6 \\
\hline Intermediate precision $(\% \mathrm{RSD})^{\mathrm{a}}$ & 1.02 & 0.38 & 1.44 \\
\hline Pooled result for mean $\%$ Assay ${ }^{b}$ & 100.3 & 100.6 & 100.9 \\
\hline Pooled for $(\% \text { RSD })^{\mathrm{b}}$ & 0.79 & 0.73 & 0.99 \\
\hline \multicolumn{4}{|l|}{ Accuracy } \\
\hline $50 \%$ level (Mean $\%$ Recovery $\mathrm{n}=3)^{\mathrm{c}}$ & 101.1 & 100.2 & 100.9 \\
\hline $100 \%$ level (Mean $\%$ Recovery $n=3)^{c}$ & 100.3 & 98.9 & 100.1 \\
\hline $150 \%$ level (Mean $\%$ Recovery $\mathrm{n}=3)^{\mathrm{c}}$ & 101.1 & 100.5 & 101.3 \\
\hline Accuracy $(\% \mathrm{RSD})^{\mathrm{d}}$ & 0.63 & 1.10 & 0.65 \\
\hline Stability in analytical solution $-24 \mathrm{~h}, \%^{\mathrm{e}}$ & 98.5 & 100.4 & 101.8 \\
\hline
\end{tabular}

${ }^{a}$ Determine on six sample preparation $(n=6),{ }^{b}$ Pooled result of Repeatability and Intermediate precision $(n=12),{ }^{c}$ Limit of recovery is $95 \%$ to $105 \%,{ }^{d}$ Pooled $\%$ RSD for the recovery result for triplicate preparation at 50\%, 100\%, 150\% level. ${ }^{e}$ Assay calculated against freshly prepared sample (\%) $n=$ No. of sample prepared. 


\section{Accuracy by recovery}

The amount recovered is within $\pm 2 \%$ of amount added, which indicates that the method is accurate. The result for Accuracy is as shown in Table 5

\section{Robustness}

It has been observed that the small changes in the chromatographic condition do not have impact on the System suitability parameter such as tailing factor, Resolution, theoretical plates and capacity factor as well as on the assay value in every change. Hence the method is considered to be robust against the small changes in the chromatographic condition. The results are represented in Table 6.

Table 6. Robustness impact of system suitability parameter and assay value

\begin{tabular}{|c|c|c|c|c|c|c|c|c|c|c|}
\hline \multirow{3}{*}{ Robustness parameter } & \multicolumn{10}{|c|}{ System suitability parameter / Test } \\
\hline & \multicolumn{3}{|c|}{$\begin{array}{l}\text { Capacity } \\
\text { factor(k') }\end{array}$} & \multicolumn{2}{|c|}{$\begin{array}{l}\text { Resolution } \\
\text { (R) }\end{array}$} & \multicolumn{3}{|c|}{$\begin{array}{c}\text { Column } \\
\text { efficiency(N) }\end{array}$} & \multicolumn{2}{|l|}{ Assay } \\
\hline & THP & TFP & CLP & THP TFP & CLP & THP & TFP & CLP THP & TFP & CLP \\
\hline No change ( $\mathrm{Re}$ & 2.81 & 5.31 & 1.68 & 4.75 & 5.01 & 4188 & 7669 & 689899.7 & 100.4 & 101.3 \\
\hline Colur & 2.88 & 5.26 & 1.62 & 4.68 & 4.89 & 4589 & 8039 & 736198.1 & 100.3 & 100.5 \\
\hline $\mathrm{Co}$ & 2.88 & 5.16 & 1.59 & -4.71 & 4.77 & 4828 & 8358 & 766298.3 & 100.3 & 10 \\
\hline Flov & 3.29 & 6.11 & 1.60 & -4.75 & 5.06 & 3757 & 7995 & 7247100.5 & 100.4 & 10 \\
\hline $1.1 \mathrm{~mL} / \mathrm{min}$ & 2.53 & 4.72 & 1.72 & 4.58 & 4.92 & 4685 & 7572 & $7077 \quad 100$ & 100.6 & 100.2 \\
\hline $\begin{array}{l}\text { Mobile phase proportion } \\
\text { Buffer:Methanol 13:87 (v/v) }\end{array}$ & 2.68 & 4.44 & 1.59 & - 3.45 & 4.13 & 4149 & 7938 & 6869100. & 100.4 & 100.6 \\
\hline $\begin{array}{l}\text { Mobile phase proportion } \\
\text { Buffer:Methanol 17:83 (v/v) }\end{array}$ & 3.15 & 6.30 & 1.63 & 6.18 & 5.51 & 4525 & 8340 & 8078100.5 & 100.2 & 100.6 \\
\hline
\end{tabular}

\section{Stability in analytical solution}

Sample solution did not show any appreciable change in assay value when stored at ambient temperature $\left(25^{\circ} \mathrm{C}\right)$ up to $24 \mathrm{~h}$. Assay results are presented in Table 5.

\section{Application for assay of pharmaceutical tablets}

The validated HPLC method was used for the simultaneous determination of THP, TFP and CLP in their combined dosage form available in market viz Ralicam-SF Tablets. Six samples were weighed separately and analysed. The results, expressed as percentage drug recovery related to label claim, are informed in Table 7 . These indicate that the amounts of each drug in the tablets are within the general pharmacopoeial requirement of $95 \%$ to $105 \%$ of the corresponding labels claims.

Table 7. Assay of THP, TFP and CLP in their combined tablet formulations.

\begin{tabular}{cccc}
\hline \multirow{3}{*}{ Sample No. } & \multicolumn{3}{c}{ \% Assay } \\
\cline { 2 - 4 } & \multicolumn{2}{c}{ RELICALM SF Tablets } \\
\cline { 2 - 4 } & THP & TFP & CLP \\
\hline 1 & 100.1 & 99.5 & 99.9 \\
2 & 100.2 & 99.6 & 100.1 \\
3 & 100.5 & 99.2 & 101.2 \\
4 & 101 & 101.1 & 100.6 \\
5 & 99.5 & 100.5 & 99.6 \\
6 & 100.2 & 99.9 & 100.5 \\
Mean & 100.25 & 99.97 & 100.32 \\
\% RSD & 0.49 & 0.71 & 0.57 \\
\hline
\end{tabular}




\section{Conclusion}

The HPLC method developed for the Quantification of THP, TFP and CLP from formulation is fully validated as per International Conference on Harmonisation (ICH) Guidelines, thus indicating general applicability of the method for routine analysis of formulation those marketed in regulated countries.

The proposed method is simple, accurate, precise, robust, and specific and has the ability to separate the THP, TFP, CLP and other degradation product from each other and excipients in the tablets. Further short span of time for analysis reveals the cost saving of organic solvent and time saving which is very important from the costing incurred for the product by company. Sample solution stability was established by determination of assay over the period of $24 \mathrm{~h}$. The simplicity of the method allows for application in laboratory for routine quality check as well as for stability studies for formulated product. Also it can be utilized for the determination of content uniformity and dissolution profiling of this product. Overall, the method provides high throughput solution for determination of THP, TFP and CLP in the tablets with excellent selectivity, precision and accuracy.

\section{Reference}

1 http://www.drugbank.ca/drugs/DB00376

2 Rele S Kapoor and Mukherjee T, Res Chem Intermed., 2003, 29(6), 649-658

3. http://www.stjuderesearch.org/guy/data/parasite_bioactives_screen/MAL_3D7/ Results/54.html

4 http://chrom.tutms.tut.ac.jp/JINNO/DRUGDATA/62chlorpromazine.html\#Property

5 Cápka V, Xu Y and Chen YH, J Pharm Biomed Anal., 1999, 21(3), 507-517.

6 Eileen Bargo, J Pharm Sci., 1979, 68(4), 503 - 505.

7 Jilin Yan, Jifeng Liu, Weidong Cao, Xiuhua Sun, Xiurong Yang and Erkang Wang; Microchemical Journal, 2004, 76(1-2), 11-16.

8 Hua Lia, Peng-hui Wanga, Chao Lia, Hong Wanga and Hua-shan Zhang, Microchemical Journal, 2008, 89(1), 34-41.

9 Chin-Kwan Maa, Chuen-Shing Moka and Ping-Kay Honb, Analytica Chimica Acta., 1995, 314(1-2), 77-85.

10 Suling Feng1 and Limin Guo1, Chemical Papers, 2008, 62(4), 350-357.

11 Poirier M A, Curran N M, McErlane K M and Lovering E G, J Pharmaceutical Sciences, 1979, 68(9); 1124 - 1127.

12 Mcclean S, O'kane E J and Smyth W F, J Chromatogr B, 2000, 740(2), 141-157.

13 Einosuke Tanakaa, Takako Nakamuraa, Masaru Teradab, Tatsuo Shinozukac, Chikako Hashimotod, Katsuyoshi Kuriharad and Katsuya Hondaa, J Chromatogr B., 854(1-2), 2007, 116-120.

14 Akemi Marumo, Takeshi Kumazawa, Xiao-Pen Lee, Koichiro Fujimaki, Ayako Kuriki, Chika Hasegawa, Keizo Sato, Hiroshi Seno, Osamu Suzuki; J AOAC International, 2005, 88(6), 1655-1660.

15 El-Gindy A., El-Zeany B, Awad T and Shabana M M, J Pharmaceutical Biomed Anal., 2002, 27(1), 9-18.

16 Katarzyna Madej, Andrzej Parczewski and Maria Kała, Summary Toxicology Mechanisms and Methods, 2003, 13(2), 121-127.

17 Abubakr M Idris, J Pharma Toxico Methods, 2007, 56(3), 330-335.

18 Alaa El-Gindy, Badr El-Zeany, Tamer Awad and Marwan M. Shabana, J Pharma Biomedical Anal., 2001, 26(2), 203-210. 
19 Moisés Knochen, Carmen Altesor and Isabel Dol, Anal., 1989, 114, 1303 - 1305

20 Patel S K and Patel N J, Chromatographia, 2009, 69; 3-4.

21 Midha K K, Hawes E M, Korchinski E D, Hubbard J W, McKay G, Cooper J K and Roscoe R M H, Biopharmaceutics \& Drug Disposition, 2006, 5(1), 25-32.

22 Guiying Jina, Fei Huanga, Wei Lia, Shaoning Yua, Song Zhanga and Jilie Kong, Talanta, 2008, 74(4) 815-820.

23 Pérez-Ruiz T, Martínez-Lozano C, Tomás V, de Cardona C S, Talanta, 1993, 1361-1365

24 Midha K K, McKay G, Chakraborty B S, Young M, Hawes E M, Hubbard J W, Cooper J K and Korchinski E D, J Pharm Sci., 1990, 79(3), 196-201.

25 Bo Wena and Mingyan Zhou, Chemico-Biological Interactions, 2009, 181(2), 220-226.

26 Henry A Okeri, Peter O Alonge and Emadoye Etareri, Int J Health Res., 2008, 1(1), 21-26

27 Christopher L Boehme and Henry W Strobel, J Chromatography B Biomedical Sciences and Applications, 1998, 718(2), 259-266.

28 Allender W J, Archer A W and Dawson A G, J Anal Toxicol, 1983, 203-206.

29 Onkubo T, Shimoyama R and Sugawara K, J Chromatogr., 1993, 614(2), 328-332.

30 Erzen N K, Slov Vet Res., 2001, 38(4), 297 - 304.

31 Takahashi DM, J Pharm Sci., 1980, 69(2), 184-187.

32 Midha K K, Cooper J K, McGilveray, Bulterfield A G and Hubbard J W, J Pharm Sci., 1981, 70(9), 104-106.

33 Daniel Daniela and Gutz Ivano G R, J Pharma Biomed Anal., 2005, 37(2), 281-286.

34 Mojtaba Shamsipur, Bahram Hemmateenejad and Morteza Akhond, J AOAC International, 85(3), 555-562.

35 Murty B S R and Baxter R M, J Pharm Sci., 1970, 59(7), 1010 -1011.

36 Gruenke L D, Craig J C, Klein F D, Nguyen T L, Hitzemann B A, Holaday J W, Loh H H, Braff L, Fischer A and Glick I D, Biomed Mass Spectrom, 1985, 12(12), 707 - 713.

37 Motoyasu Sato and Toshiyuki Mitsui, Anal Sci., 1994, 10(3), 485-490.

38 Chan T L, Sakalis G and Gershon S, Raven Press, New York, 1974, 9, 305 - 333.

39 Daniel D and Gutz I G, J Pharm Biomed Anal., 2005, 37(2), 281- 286.

40 Dermis S and Biryol I, Analyst, 1989, 114(4), 525 - 526.

41 Sales M G F, Tomas J F C and Lavandeira S R, J Pharm Biomed Anal., 2006, 41(4), 1280-1286.

42 Zarembo J E, Warren R J and Staiger D B, Assoc off Anal Chem., 1978, 61(1), 52-54.

43 Midha K K, Loo J C K, Hubbard J W, Rowe P L and McGliveray L J, Clin Chem., 1979, 25(1), $166-168$.

44 Kaul P N, Conway M W, Clark M L and Huffine J, J Pharm Sci., 2006, 59(12), 1745- 1749.

45 Shi W, Yang J and Huang Y, J Pharm Biomed Anal., 2004, 37(2), 281 - 286.

46 Minakata K, Suzuki O, Ishikawa Y, Seno H and Asano M, Forensic Sci Int., 1991, 50(2), 167 - 177.

47 United States Pharmacopeia (USP 30). 2007. The United States Pharmacopeial Convention. Rockville, MD, U. S. A.

48 British Pharmacopoeia (BP) 2009; The British Pharmacopoeia Secretariat, Market Towers, 1 Nine Elms Lane, London, SW8 5NQ

49 International Conference on Harmonisation (ICH), Q2(R1), Validation of analytical procedures; text and methodology. 


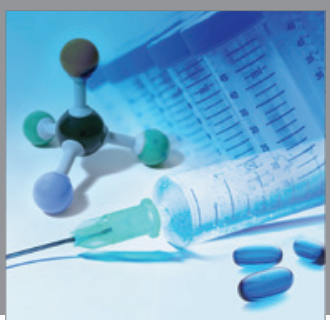

International Journal of

Medicinal Chemistry

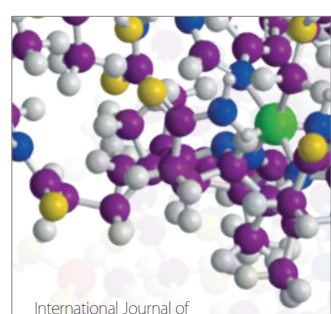

Carbohydrate Chemistry

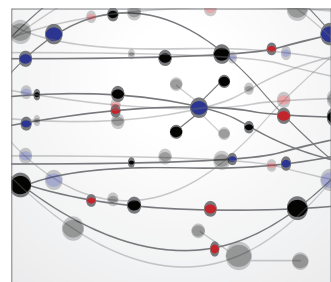

The Scientific World Journal
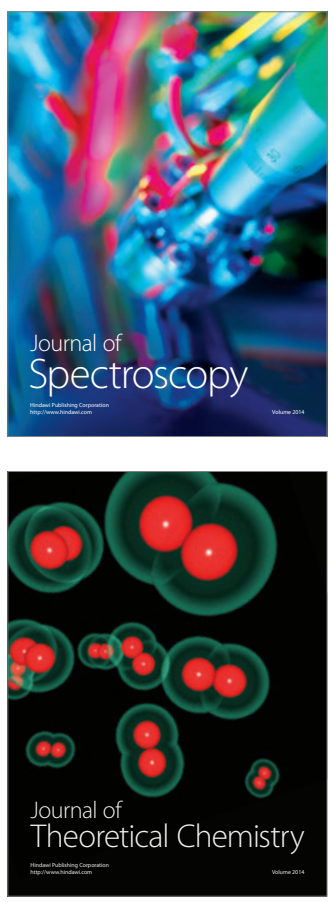
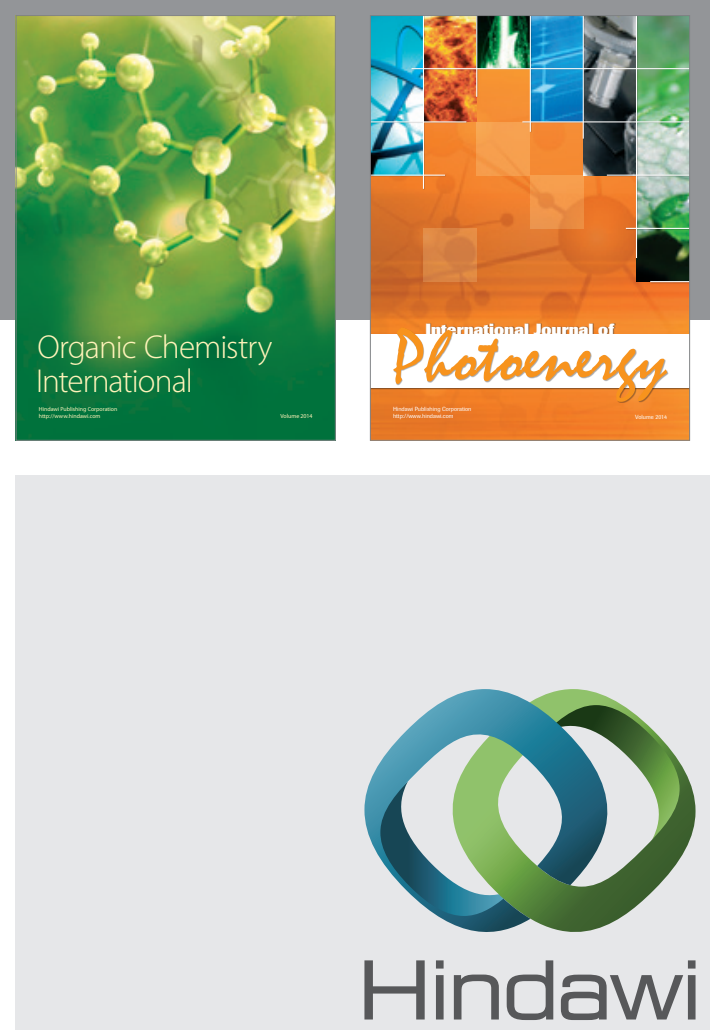

Submit your manuscripts at

http://www.hindawi.com
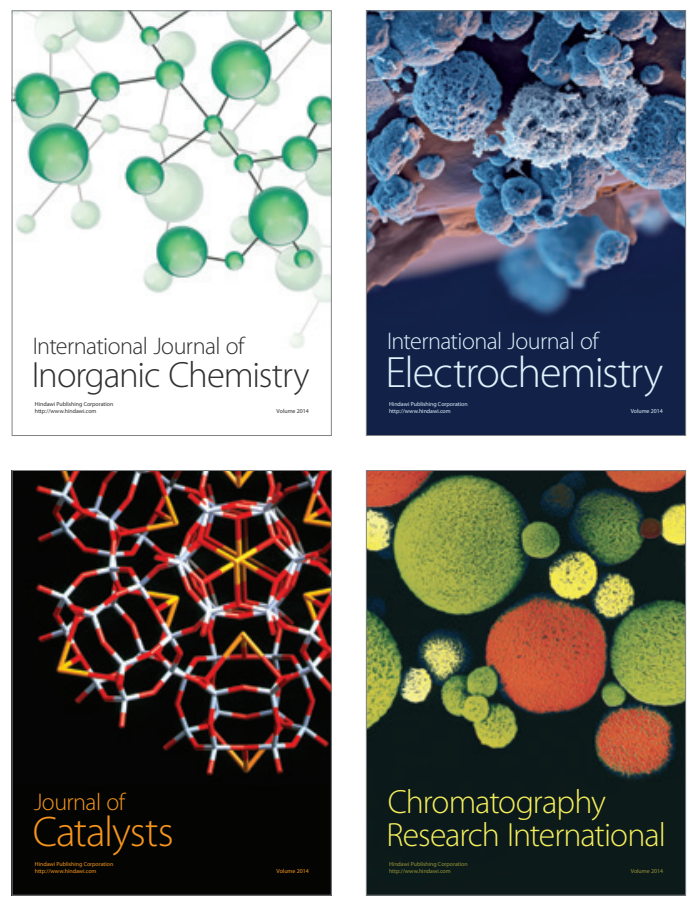
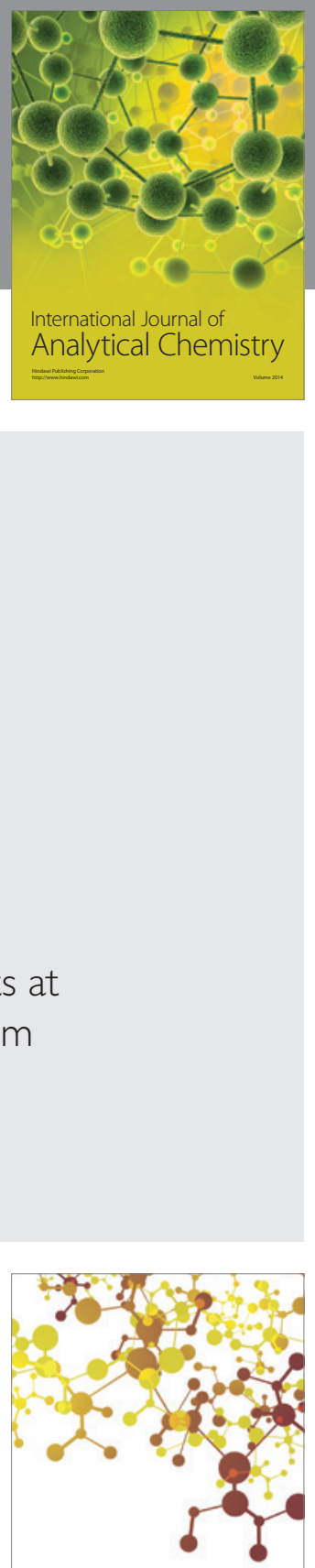

Journal of

Applied Chemistry
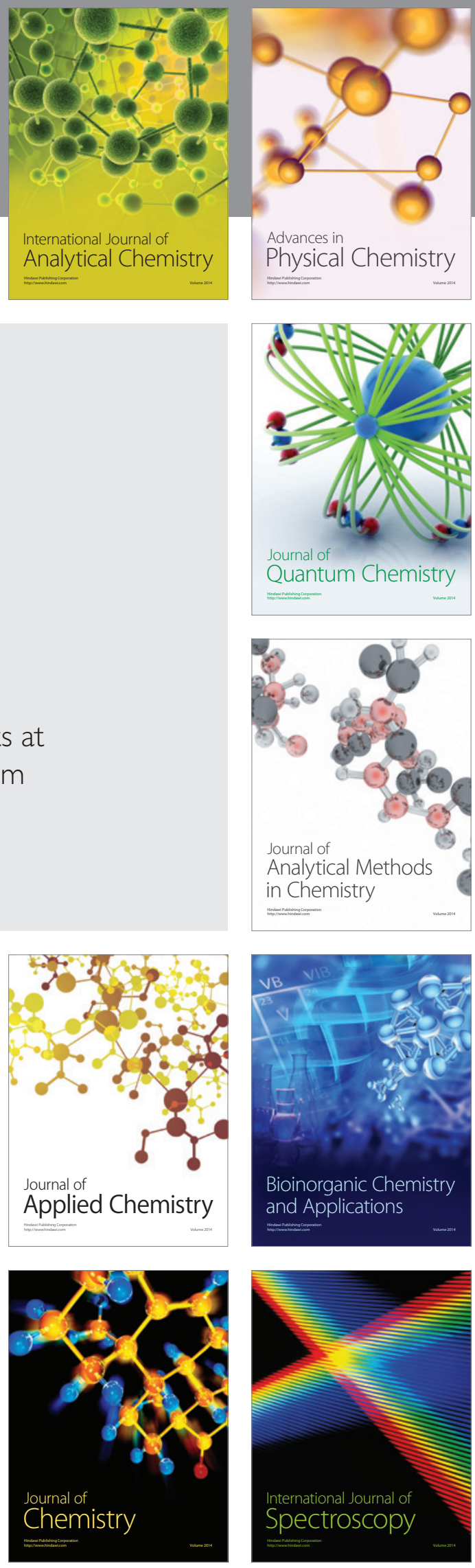